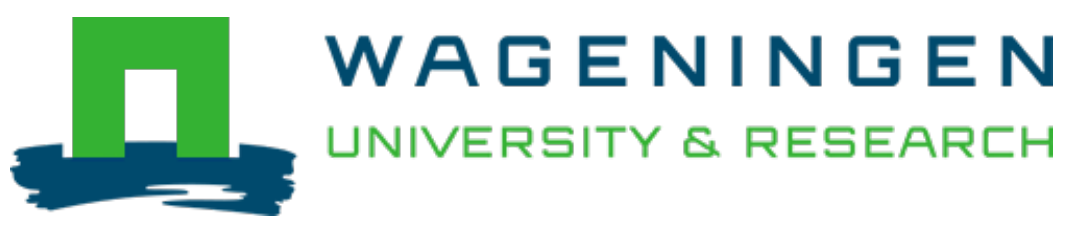

\title{
A hierarchical classification of farm systems
}

Experimental Agriculture

Fresco, L.O.; Westphal, E.

https://doi.org/10.1017/S0014479700100146

This publication is made publicly available in the institutional repository of Wageningen University and Research, under the terms of article $25 \mathrm{fa}$ of the Dutch Copyright Act, also known as the Amendment Taverne. This has been done with explicit consent by the author.

Article $25 \mathrm{fa}$ states that the author of a short scientific work funded either wholly or partially by Dutch public funds is entitled to make that work publicly available for no consideration following a reasonable period of time after the work was first published, provided that clear reference is made to the source of the first publication of the work.

This publication is distributed under The Association of Universities in the Netherlands (VSNU) 'Article 25fa implementation' project. In this project research outputs of researchers employed by Dutch Universities that comply with the legal requirements of Article $25 \mathrm{fa}$ of the Dutch Copyright Act are distributed online and free of cost or other barriers in institutional repositories. Research outputs are distributed six months after their first online publication in the original published version and with proper attribution to the source of the original publication.

You are permitted to download and use the publication for personal purposes. All rights remain with the author(s) and / or copyright owner(s) of this work. Any use of the publication or parts of it other than authorised under article $25 \mathrm{fa}$ of the Dutch Copyright act is prohibited. Wageningen University \& Research and the author(s) of this publication shall not be held responsible or liable for any damages resulting from your (re)use of this publication.

For questions regarding the public availability of this publication please contact openscience.library@,wur.nl 


\title{
A HIERARCHICAL CLASSIFICATION OF FARM SYSTEMS
}

\author{
By L. O. FRESCO and E. WESTPHAL \\ Department of Tropical Crop Science, \\ Agricultural University, Wageningen, The Netherlands
}

(Accepted 15 March 1988)

\begin{abstract}
SUMMARY
A framework is proposed for the classification of farm systems, which are defined as decisionmaking units comprising farm household, cropping and livestock systems that transform bnd, capital and labour into products for consumption and sale. Two general principles underlying the classification are outlined. First, since farm systems are embedded in a hierarchical structure, the classification is based on the characteristics of the underlying systems and their interactions. Secondly, ecological factors, i.e. physical and biological parameters, are the primary determinants of farm systems. Changes in farm systerns, at least in the foreseeable future, depend on the development of socio-economic variables. The classification is summarized in a set of comprehensive tables.
\end{abstract}

L. O. Fresco y $\mathrm{E}$. Westphal: Una clasificación jerárquica de sistemas agricolas.

\section{RESUMEN}

Se propone un marco para la clasificación de sistemas agrícolas, que se definen como unidades tomadoras de decisiones que comprenden la 'familia' agrícola, los sistemas de cultivos y ganadero que transforman la tierra, el capital y el trabajo en productos para el consumo y la venta. Se resumen dos principios generales que forman la base de la clasificación: en primer lugar, ya que los sistemas agrícolas se encuentran dentro de una estructura jerárquica, la clasificación se basa sobre las características de los sistemas subyacentes y sus interacciones; en segundo lugar, los factores ecológicos, es decir, parámetros físicos y biológicos, son los determinantes primordiales de los sistemas agrícolas. Los cambios en los sistemas agrícolas, por lo menos en ei futuro previsible, dependen del desarrollo de variables socioeconómicas. La clasificación se resume en una serie de cuadros amplios.

\section{INTRODUCTION}

There is general agreement in the international scientific community that agricultural technology must be increasingly adapted to the specific conditions of third-world farmers who operate in a wide range of ecological zones and under diverse socio-economic constraints (CGIAR/TAC, 1985). In particular, in dealing with less favourable environments a broader range of agricultural technology is required. The development of such technology necessitates a more detailed knowledge of the existing farm systems and ecological and socio-economic environments. Characterizing farm systems is often exceedingly difficult because of the complexity and heterogeneity of the factors involved. A balance must be struck between the uniqueness of each farm (and farm household) and the characteristics it shares with other farms and that are relevant for the adoption of technology. Much of the discussion about the need for locationspecificity and adaptive research deals with the classification of farm systems, 
and it would be of great help if one were to find meaningful ways to classify them, that is to say ways that would reveal predictive information concerning the requirements of agricultural technology and its biological performance and allow extrapolation of research results. In this article an attempt is made to raise some of the issues involved in the classification of farm systems.

\section{PAST ATTEMPTS AT CLASSIFICATION}

There are basically two ways to classify farm systems. First, the farm systems of the world can be grouped together in broad classes that reflect fundamental structural differences, for example, plantation systems, tillage systems (with and without livestock), alternating systems and grassland systems (Duckham and Masefield, 1970). The other approach is that used by Grigg (1974), who makes explicit reference to geographical units, for example, Mediterranean agricultural systems. These classifications and others have in common that they combine economic and biological factors. Whether the classification involves the basic four (arable cropping, crop-livestock, plantation and ranging) or a multitude of classes, its applicability in any given geographical region is limited. The main usefulness of this type of broad classification lies in its indication of the relative importance of different classes of farm system and their relevance to the setting of priorities in international agricultural research. Others have attempted a classification of a specific system type, such as that for agro-forestry systems (Nair, 1985) or shifting cultivation (Miracle, 1967).

The best known classification in this tradition is that of Ruthenberg (1980) who provides innumerable examples of seven basic types of system. While the value of Ruthenberg's work is unquestionable, two comments are necessary. First, most of Ruthenberg's examples concern cropping or livestock systems and not farm systems. As a result, he hardly considers farm systems that consist of more than one sub-system, be it cropping or livestock. Interactions between sub-systems are therefore neglected. This is an omission, because improvements in one sub-system are often constrained, or facilitated, by the characteristics of others. Secondly, Ruthenberg makes little distinction between levels of analysis. As a result, constraints imposed by higher level systems and limitations derived from lower level systems cannot be taken into account adequately.

Once broad categories of systems are defined, more detail is obtained by the classification of farms or other units in a specific environment. Many studies of colonial agriculture resulted in the classification of farm systems in a given (sub)region. A classical example of this type of work is provided by Allan et al. (1945) in their interdisciplinary study of the Plateau Tonga of Zambia where farms were classified according to land area and volume of maize produced for sale. Sometimes such a classification concerns different classes of farm systems (for example, semi-nomadic cattle ranging as well as arable farming), but often it deals with distinctions within the same class or sub-class of system (for 
example, wheat farms of varying sizes with animal traction or tractors). The literature abounds with examples of this kind of classification, under numerous headings such as target groups or recommendation domains. In fact, few agricultural research programmes are likely to start developing agricultural technology without some inventory of potential user groups. The point is that there are numerous, idiosyncratic ways to classify farms that are often not comparable between programmes.

Where larger spatial units than the farm are concerned other methods of classification for specific regions have proved useful, in particular agro-climatic mapping and land evaluation (Beek, 1978). Nevertheless, these methods do not deal with farm level variables and do not provide any insight into farmer decision making, in particular because crucial variables such as labour inputs are excluded.

The weakness of these past attempts at the classification of farm systems is that they provide little systematic insight into the way the classification relates to the development of agricultural technology. Furthermore all these approaches classify elements of farm systems (livestock, crops, capital use), but do not do justice to the interaction of the elements which make up the system. Farm systems that are classified in the same category may react quite differently depending on characteristics that may not be included in the classification, such as off-farm income or household composition. This suggests that there may be some benefit in classifying farms as systems, that is to say, composed of related parts, rather than on the basis of loosely connected criteria. An attempt to explore a systems perspective on the classification of farm systems in the tropics follows below.

\section{AGRICULTURE AS A HIERARCHY OF SYSTEMS}

Systems theory applied to the study of tropical farming

The application of systems theory to the study of agriculture has been advocated by many workers (e.g. Spedding, 1979). However, systems concepts have often been applied in a rather arbitrary way, in particular in the farm systems literature, resulting in a range of different 'models' (e.g. Collinson, 1984; McDowell and Hildebrand, 1983). Hart and Pinchinat (1982) were the first to explore the usefulness of an ecological systems approach to small farmer agriculture, and this article seeks to build upon their efforts.

A system is defined here, following Odum (1983), as an arrangement of components or parts that interact according to some process and transform inputs into outputs. By analogy with ecology, agriculture can be described as a hierarchy of systems, ranging from the cell at the lowest level, through the plant or animal organs, the whole plant or animal, the crop or herd, the field or pasture, and the farm, to complex ecosystems such as the village and watershed, culminating in the agricultural sector at the highest level, as shown in a simple diagrammatic form in Fig. 1. Each of the units (cell, plant, herd, field 


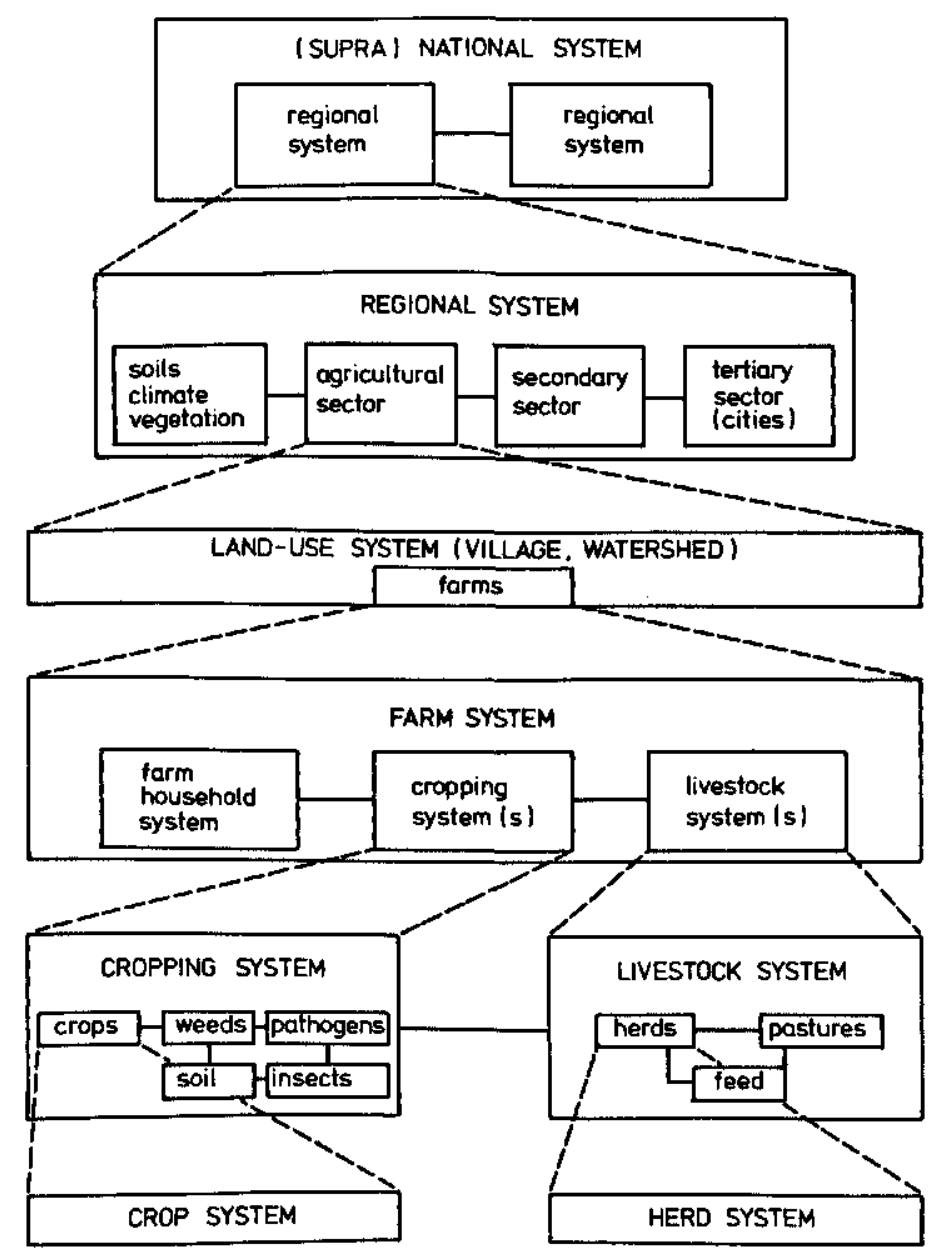

Fig. 1. Agriculture as a hierarchy of systems (from Fresco, 1986).

and so on) constitutes a system, since each involves an arrangement of parts that transforms inputs into outputs. These are linked in a hierarchical way: each system comprises lower level systems as sub-systems and is at the same time a part (or sub-system) of a higher level system, the supra-system. For example, plants are sub-systems of crops, which in turn are sub-systems of fields, while the farm is the supra-system of the field. Thus, at each level one finds a system of which the components (or sub-systems), inputs and outputs can be determined.

Systems can be considered similar if they are similar in structure, i.e. in the characteristics of their components and component interactions, and in function, i.e. in the way inputs are transformed into outputs. Similarity and degrees of similarity between systems provide the basis for their classification. 


\section{Hierarchical structures (from plant to region)}

Table 1 identifies levels of analysis, systems, system components, inputs and outputs, as well as units of observation. The levels below the plant system have been disregarded because they are less relevant to most agronomists (in contrast, for example, to plant physiologists). At the lowest level considered here, one finds the plant system, of which the organs (leaves, roots and so on) are the main components. Plants process solar energy, nutrients and water into biomass.

The next level up is occupied by the crop system, with crops, i.e. the plant sub-systems and their interactions, as the main components. The crop system is defined as an arrangement of crop populations that transform solar energy, nutrients, water and other inputs into useful biomass. The crops in the crop system can be of different species and variety, but they only constitute one crop system if they are managed as a single unit. Different techniques are applied to obtain various spatial arrangements of plants to constitute a crop (sole cropping and multiple cropping). At this level, one is interested in interactions between plants rather than in individual plants. The next system level is the cropping system, with the field as the corresponding unit of observation. The cropping system is a land-use unit comprising soil, crop, weed, pathogen and insect sub-systems, that transforms solar energy, water, nutrients, labour and other inputs into food, feed, fuel, fibre and pharmaceuticals. An important

Table 1. Agriculture as a hierarchy of systems (from Fresco, 1986)

\begin{tabular}{lll}
$\begin{array}{l}\text { Ecological } \\
\text { level }\end{array}$ & System & \multicolumn{1}{c}{$\begin{array}{c}\text { Components/ } \\
\text { sub-systems }\end{array}$} \\
Individual & plant system & $\begin{array}{l}\text { organ (roots, leaves } \\
\text { etc.) }\end{array}$ \\
Population & crop system & $\begin{array}{l}\text { crop(s), (plant sys- } \\
\text { tems) (including } \\
\text { perennials) } \\
\text { animals }\end{array}$
\end{tabular}

Community cropping system

livestock system herds, pastures

Ecosystem farm system

Complex regional system ecosystem (village, landuse systems) crop systems, weeds, pathogens, insects, soil

cropping system, livestock system, farm household

climate, soils, vegetation, primary sector, secondary sector, tertiary sector, human resources
Unit of Inputs Outputs observations

solar energy, biomass plant nutrients, water

solar energy, biomass crop nutrients, water

plant biomass, animal biomass, herd, field water, labour food, fibre, fuel, and manage- feed ment

external

inputs

land, labour, animal biomass pasture feed

land, labour, crop and live- farm, farm capital stock for consumption and sale

matter, infor matter, information, energy mation, energy household

region (watershed, village) 
characteristic of the cropping system is the sequence of cropping, or cropping and fallow, on a given piece of land.

Parallel to the cropping system is the livestock system, defined as a land-use unit comprising pastures and herds and auxiliary feed sources transforming plant biomass into animal products. Important characteristics are the sequence of grazing on a given piece of land as well as the mobility of both the animals and those who tend them.

The next level in the hierarchy is the farm. Most authors speak of the "farming system' if they study the farm as a system (notable exceptions being Ruthenberg (1980) and Hart and Pinchinat (1982)), but 'farm system' is more correct and will therefore be adhered to here. The term farming system will be reserved for a class of similarly structured farm systems.

The farm system is a decision-making unit comprising the farm household, cropping and livestock systems, that transforms land, capital (external inputs) and labour (including genetic resources and knowledge) into useful products that can be consumed or sold. The farm system comprises the cropping system(s), the livestock system(s) and the farm household. Each of these constitutes a complex sub-system by itself. In the tropics, nearly all farms have more than one cropping and/or livestock system, for example, upland crops as well as irrigated paddy fields and home gardens, in addition to farmyard animals or herds of small ruminants. Cropping and livestock systems frequently interact, for instance if crop residues are fed to animals or manure and animal traction are used for the crops.

The farm household consists of a group of people, often related, who individually or jointly provide the management, labour, capital, land and other inputs for the production of crops and livestock, and who consume at least part of the farm produce. The farm household is thus the centre of consumption, resource allocation, management and labour, and can consist of more or less autonomous sub-systems. Management is one of the crucial variables here. In systems terms, it regulates component interactions within the system so that an optimal quantity of useful products is obtained. Management implies decisions about objectives (such as whether to grow cash or food crops), and about how deviations from standards have to be corrected during implementation. Offfarm activities can be an important separate element in the farm household system.

All other system levels above the farm system have been summarized as the regional system in Table 1 . This is a complex large-scale land-utilization unit which produces and transforms primary (agricultural) products and involves a large service sector, including urban centres. The term regional system, although awkward, is preferable to agricultural system, because the latter does not indicate the level of analysis and does not do justice to non-agricultural activities. In regional systems, agricultural and socio-economic processes are closely linked. Intermediate levels between the farm system and the regional system can be villages or landscape units such as watersheds or valleys. The regional 
system can be analysed from an ecological and/or a socio-economic perspective. Ecologically speaking, it consists of climate, soils, vegetation and human resources. Soils (in the plural) refer to land units as well as land-utilization units. In the economic sense, regional systems comprise a primary production sector, a secondary sector (processing agricultural products) and a tertiary (services, marketing and urban) sector. The primary production sector comprises all the farms in the region.

\section{Types of cropping and livestock systems}

A classification of farm systems depends, among other things, on a classification of the cropping and livestock systems that constitute its sub-systems.

Cropping systems are classified here, broadly following Ruthenberg (1980) and Lagemann (1977), according to land-use intensity. Eight principal types of cropping systems are distinguished.

Shifting systems. Cropping systems characterized by an alternation between cropping for a few years on selected and cleared plots, and a period of fallowing of varying length, during which the soil is rested. Shifting cultivation is an extensive cropping system characterized by an extensive period of fallowing (cf. Allan, 1965), whereas fallow systems are more intensive systems characterized by a regular sequence of crop and fallow years. They can be further sub-divided according to the type of fallow vegetation (bush and grass fallow systems).

Ley systems. Cropping systems characterized by a more or less regular alternation between arable farming and leys, temporary pastures of grass or grass and legumes utilized for livestock production. There are two types: unregulated ley systems and regulated ley systems.

Permanent upland cultivation. Cropping systems characterized by a permanent division within the holding between arable land and grassland, clearly demarcated fields, and a predominance of annual and biennial crops.

Irrigation farming. Cropping systems characterized by the additional supply of water with a view to reducing the length and the frequency of soil moisture stress, in order to allow the permanent cultivation of crops. One may distinguish between supplementary and full irrigation. Because of the wide occurrence of this type of cropping system, a further division is made on the basis of the dominant crop system into wet-rice systems and all other arable irrigation systems.

Perennial crop cultivation. Cropping systems characterized by the permanent use of the land by the same crop, primarily perennial, grown on estates or smallholdings. This type includes all agroforestry systems.

Gardening (or compound cultivation). Cropping systems characterized by the permanent use of small, mostly fenced, plots at a short distance from the homestead with a variable number of annual, biennial and/or perennial intercrops giving rise to a multi-storey physiognomy.

Similarly, five types of livestock system may be distinguished. 
Total nomadism. Extensive livestock systems characterized by the permanent migration of herds and nomads.

Nomadism. These extensive livestock systems can be divided into two main types: semi-nomadism and partial nomadism. Semi-nomadism is characterized by the seasonal migration of herds and semi-stationariness of the nomads, with some supplementary arable farming and transhumance of herds. Partial nomadism is characterized by the communal use of grazing land by herds, the stationariness of the nomads and the dominance of arable farming; the integration of cattle into this system of farming varies (cf. McIntire and Gryseels, 1987).

Ranching. Extensive livestock systems characterized by controlled grazing of large stretches of land covered with natural vegetation and by stock-keeping only. Sometimes cropping of arable fodder is carried out.

Stationary animal husbandry. Intensive livestock systems characterized by controlled grazing on artificial pastures. Two types can be distinguished: mixed farming and cattle farming.

Small-scale stationary animal husbandry. Intensive livestock systems characterized by a diversity of animals, poultry, pigs, goats or fish raised in small numbers on or near the farm homestead, often on by-products of the farm and with primarily a subsistence perspective.

This classification of types of cropping and livestock systems paves the way for a discussion of a classification of farm systems.

\section{A CLASSIFICATION OF FARM SYSTEMS}

The characteristics of farm systems and their sub-systems are determined by ecological and socio-economic factors. Ecological factors comprise physical basically climate and soils - and biological parameters. They shape the environment in which crops and animals grow. A range of socio-economic variables are superimposed on the ecological factors so that the original environment is modified.

\section{Ecological factors}

Climate is the starting point of the proposed classification. Five main climatic zones are distinguished (ICRISAT, 1987; Jackson, 1977; Webster and Wilson, 1980) according to average annual rainfall and rainfall distribution. Zones above $1000 \mathrm{~m}$ altitude constitute a separate ecological region. The climatic zones are further characterized by five main types of climax vegetation (Webster and Wilson, 1980) as well as by characteristic crops and livestock that can potentially be produced in each zone, with some overlapping. Soil types, although important, are not dealt with here. For the distribution of soils in the tropics by climatic regions see Sanchez (1976).

The distribution of cropping and livestock systems according to climatic zone is shown in Table 2. Soil types and population density further determine 
总

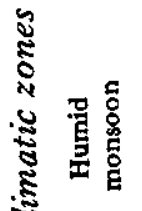

$\therefore$

赵

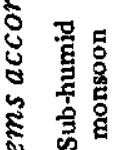

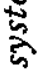

ษั

药

공

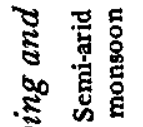

है

$\div$

密

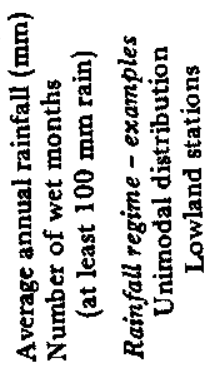

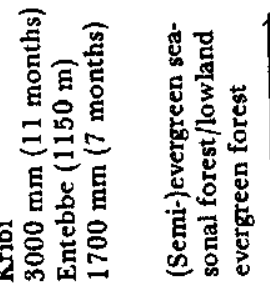

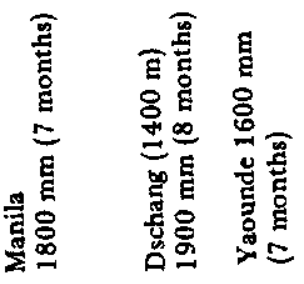
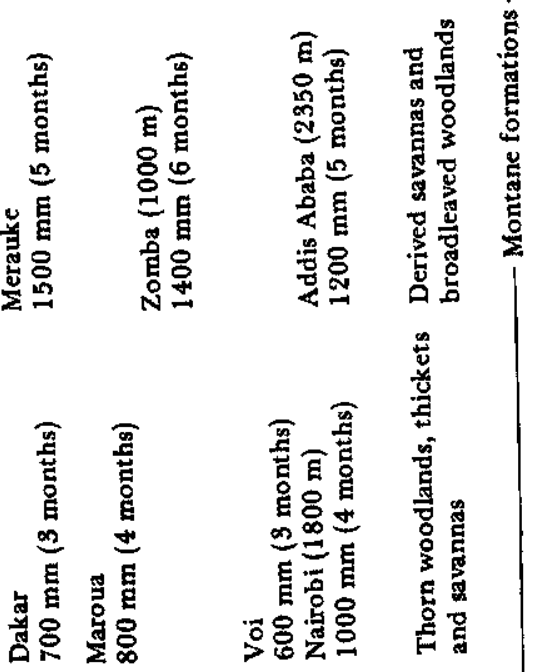

尊高

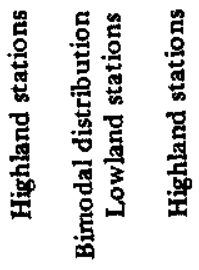

喜营

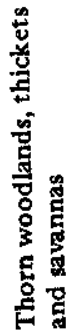

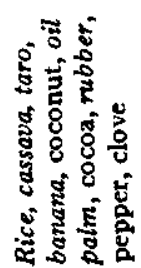

焉

(1)

In

Hib

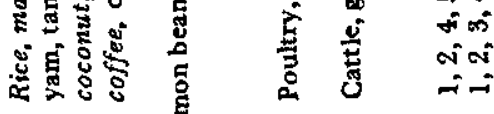

4)

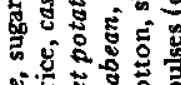

8ู

(4)

ह

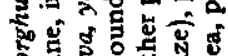

के

密安

点

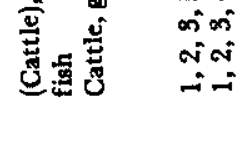

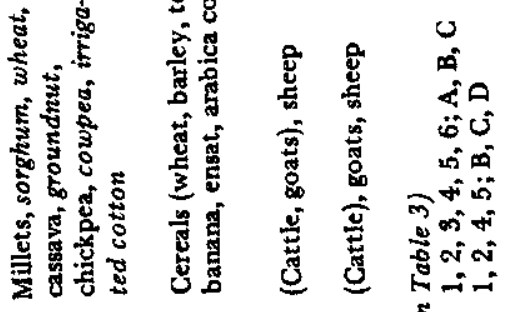

:

离
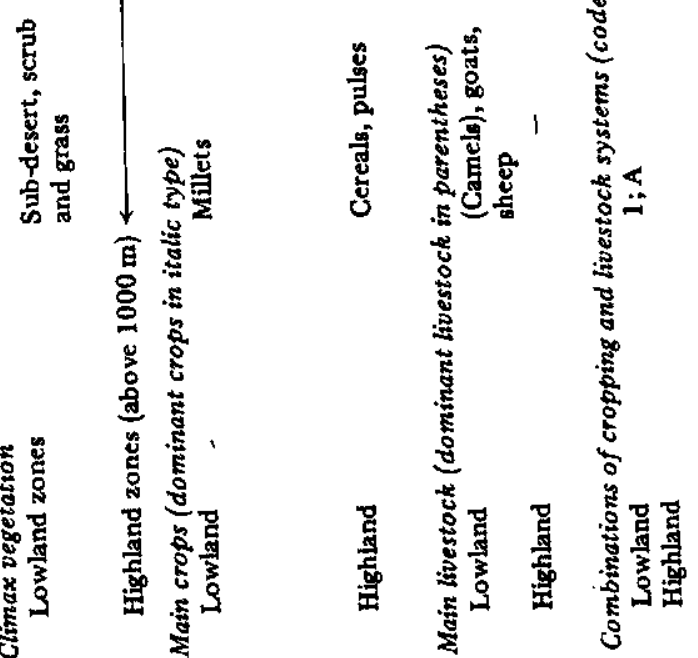
Table 3. Combinations of (a) cropping systems and (b) livestock and cropping systems occurring within farm systems

(a) Cropping system:

Gardening

Perennial crop cultivation

Wet-rice system

Arable irrigation system

Permanent upland cultivation

Ley system

Fallow system

Shifting cultivation

(b) Livestock/cropping system:

Stationary animal husbandry (small animals)

Stationary animal husbandry

Ranching

Semi-/partial nomadism

Total nomadism

$\begin{array}{cll}\text { Code } & \mathbf{1} & \mathbf{2} \\ \mathbf{8} & \mathbf{x} & \mathbf{x} \\ 7 & \mathbf{x x} & \mathbf{x x} \\ 6 & \mathbf{x x} & \mathbf{x x} \\ \mathbf{5} & - & - \\ \mathbf{4} & \mathbf{x} & \mathbf{x} \\ \mathbf{3} & \mathbf{x} & \mathbf{x} \\ 2 & \mathbf{x} & \mathbf{x} \\ \mathbf{1} & & \\ \text { Code } & \mathbf{1} & \mathbf{2} \\ \mathbf{E} & - & - \\ \mathbf{D} & - & - \\ \text { C } & - & - \\ \text { B } & \mathbf{x} & \mathbf{x} \\ \text { A } & - & -\end{array}$

xx Frequently occurring combinations, $\mathbf{x}$ infrequent combinations, - rare combinations.

Sources: Jackson (1977); Mohr et al (1972); Nieuwolt (1977); Ruthenberg (1980); Schaar (1981); Webster and Wilson (1980); Westphal (1975); Westphal et al (1981); and Annual Reports of CIAT, ICARDA, ICRISAT, IITA and IRRI.

the occurrence of cropping and livestock systems, but are not shown in this table. Ruthenberg (1980) provided a large number of examples of each of these systems, which will not be repeated here. Instead, attention is focussed on possible combinations of types of cropping and/or livestock systems within the same farm system, considering for example the conditions under which permanent upland cultivation and irrigation cultivation are found on the same farm, and how these relate, or where semi- or partial nomadism occur in combination with shifting cultivation. The most frequently occurring combinations of cropping systems, and cropping and livestock systems across climatic zones, based on a survey of a great number of descriptions of farm systems, are summarized in Table 3. The types of cropping systems that are most frequently combined with other cropping or livestock systems are wet-rice systems, perennial crop cultivation and gardening, whereas stationary animal husbandry and small-scale stationary animal husbandry are the livestock systems most often found in combination with other sub-systems of the farm system. Clearly each of the cropping systems consists of different crop systems, and each of the livestock systems may involve different animal species.

Socio-economic factors

Past attempts at the classification of farm systems have mainly been concerned with agro-ecological criteria because of the problems involved in linking the variety of socio-economic factors to patterns of agricultural production. Where socio-economic factors are taken into account, this often results in the definition of innumerable types of farm systems. Furthermore, because many 
of these factors are subject to great short- and medium-term variations - prices and household composition being the standard examples - such classifications may also be subject to rapid changes.

The problem lies in determining what socio-economic factors are relevant and have a decisive impact on the farm system. Socio-economic factors are defined here as those properties of system elements that are situated outside the physical and biological realm. Thus, socio-economic factors can be defined at each level in the hierarchy. Some of the most important (interacting) sets of socio-economic factors comprise:

Regional level factors. Population density and distribution on the one hand and infrastructure and services on the other are nearly always significant in the classification of farm systems in a given zone. These complex variables are often related, and vary also according to agro-ecological zone. Where population density tends to be low, in general, poor infrastructural development results. Nevertheless, within a given agro-ecological zone there are marked differences in these factors that have a direct bearing on farm systems. Farms situated near urban centres in such a zone will have to cope with greater population densities and will benefit from better infrastructure and more services than those in more remote areas. As a result, land-use intensity will probably increase, giving rise to changes in livestock and cropping systems.

Village/landscape unit level factors. Demographic characteristics of villages and the spatial distribution of farms and holdings with respect to landscape, water and roads are significant factors here. Within the same village or landscape unit, differential access to land and other resources must be included in any classification of farm systems.

Farm system level variables. The most significant variables at this level are farm household composition and off-farm employment and income. Furthermore, it has been repeatedly documented that the division of labour according to gender and the household life cycle influences agricultural productivity (e.g. IRRI, 1985). With respect to off-farm employment and income, systems may be predominantly subsistence oriented, market oriented or off-farm employ. ment oriented. Subsistence oriented systems are those producing a limited number of commodities primarily for consumption by the farm household and relatives and with low levels of externally purchased inputs; when marketing occurs, it is irregular (depending on cash needs) and involves small quantities. Market oriented systems are those producing a limited number of commodities for regular sale on (semi-)urban markets. Although the household may still provide most of its basic staples through agricultural production, purchased consumer goods and agricultural inputs are common. Off-farm employment oriented systems are those where farming is only undertaken by some household members and supplies a limited amount of cash and energy throughout the year. The mainstay of the farm household is provided by income from sources outside the farm, whether agricultural wage labour or non-agricultural employment. 
Households vary therefore according to their production strategy and this constitutes an important socio-economic characteristic in any farm system classification.

The regular supply of cash income to supplement agricultural production may have a significant impact on production strategies, risk aversion and the use of external inputs (e.g. Huisman, 1985).

\section{The interplay of ecological and socio-economic factors}

The environment in which farmers operate is determined by ecological factors, but substantially modified by socio-economic factors. On a human scale, ecological factors are relatively stable and predictable, notwithstanding substantial short-term fluctuations such as occur in climatic factors. Farmers' capacity to influence their physical environment is limited to slight improvements in soil fertility and structure and to micro-climate manipulation through shading or mulching. In some instances, biological factors may be influenced through the introduction or removal of plant and animal species, but these remain a function of physical factors that are not really changed themselves. Ecological factors, therefore, are the primary determinants of farm systems. The impact of agricultural technology development on these primary determinants is likely to remain limited in the foreseeable future. Conscious manipulation of climate, for example, will probably remain wishful thinking (although the unintended side-effects of large-scale pollution on agriculture may be very serious). The most important contribution of agricultural science in the ecological realm is the definition of potential production levels and limits in a given environment, and the formulation of technical pathways to fulfil that potential.

Socio-economic factors are, nearly without exception, subject to large fluctuations and shifts in trends, even within a human life time, so that the scope for changes in farm systems derives mainly from changes in these variables. The interplay between ecological and socio-economic factors at all levels in the hierarchy results in the location-specific environment in which individual farmer households operate. Within a homogenous ecological zone, differences between farm systems are primarily caused by socio-economic differences, although micro-variations in, for example, relief may also have some effects. Differences in farm systems are thus translated into differential choices of commodities and production strategies. Agricultural research can help farmers to adjust farm practices to changing socio-economic circumstances, in particular population pressure, growing commercialization and increased use of inputs.

\section{Examples of the interactions between cropping and livestock systems}

From the wealth of case studies on tropical farming, a few typical examples have been selected to illustrate the range of combinations of cropping and livestock systems and to discuss their relevance to technology development. This list, which is by no means exhaustive, shows that farm systems can best be 
characterized by a composite indicator relating to the classification of cropping and livestock systems presented in Table 2. Socio-economic and land characteristics are not included in the table nor in the indicator, because of their location-specificity. However, in each example attention is paid to variables such as infrastructure and marketing as well as to soil fertility and landscape.

Farm systems of the Western Highlands of Cameroon. Westphal et al. (1981) have described the various cropping and livestock systems in the Western Highlands: the Bamilike Plateau in the south and the so-called Grassfields in the north. On the densely populated Bamilike Plateau the farm system consists of three cropping systems: shifting cultivation/fallow systems, permanent upland cultivation and perennial cropping, in combination with small animals. Food crops are grown on the shifting or permanent fields. Maize is grown in association with groundnuts and other food crops after fallow. Depending on soil fertility, the shifting systems are coupled with permanent upland cultivation: root and tuber crops on poor soils, which are left on the field until the end of the cultivation cycle, or coffee (Coffea arabica) on more fertile soils. The coffee is planted at the same time as the food crops. After the harvest of crops such as maize, beans (common beans, cowpeas) and groundnuts, the shifting cultivation system is then effectively transformed into a system of perennial crop cultivation with coffee and sometimes bananas. The farm system thus comprises perennial fields and shifting fields, often in combination with household gardens.

On the Grassfields, the dominant farm system consists of shifting/fallow cropping, permanent upland cultivation and some perennial cropping coupled with limited numbers of cattle and small ruminants. The majority of the cattle on the Grassfields, however, belong to semi-nomadic pastoralists, who are in constant conflict with the settled farmers. Research on improving livestock production now aims to develop methods for semi-intensified systems in close association with crop production, although ranching may offer opportunities in the less populated areas.

Soil erosion is one of the major problems confronting the shifting-perennial cropping systems in both areas and the semi-nomadic livestock system in the Grassfields. The shortening of the fallow, the cultivation on steep slopes, the frequent use of bush fires as well as overgrazing lead to considerable losses of top soil. Traditional practices often provide scope for improvement and may be further researched: the use of live hedges protects the field against erosion and the movement of soil, and provides firewood; crop residues, household refuse and weeds can be incorporated as green manure. Furthermore, adequate rotations could help to overcome some of the soil fertility problems, especially if improved fallows were considered. Finally, the upgrading of existing coffee plantations and the improvement of their management would allow an intensification of the farm system, which now seems to tend towards extensification through the increase of area under cultivation. Other means for intensification would be provided by gardening. 
Permanent upland cultivation and livestock systems, Honduras. Hart (1982) has analysed quantitative input-output flows of a farm in Honduras, in an area with about $1500 \mathrm{~mm}$ rainfall distributed in a bimodal pattern. The main crops are maize, rice and common beans, while oxen and chickens are also kept. The crops are grown in two distinct types of permanent upland cultivation: maizemaize and rice (with a minor part of the area devoted to rice-bean rotation). Fertilizer and other chemical inputs are applied. Hart found a very close linkage between the livestock and cropping systems: $64 \%$ of the energy produced by the livestock system, or 115 oxen days, were used in the cropping systems (and one-third of the total number of oxen days were sold outside the farm). Many of the input-output flows, for example the amount of maize stored, or the labour input in crop production, have bimodal fluctuations, as to be expected in a two season climate. The main problems in the system seem to be the variability of crop yields, the uneven distribution of household labour throughout the year (labour peaks due to weeding rice and surplus labour in some months) and the fact that beans are not adapted to the environment. Agricultural research was therefore focussed on the introduction of a cowpea relay crop within a maize-maize sequence, and of two crops of squash (Cucurbita sp.) with a high market value. No improvements to the livestock system were suggested.

Shifting cultivation in Zăre: valley and plateau cropping systems. An example of cropping system interaction within a farm system was given by Fresco (1986) who analysed two sub-types of shifting cultivation, savanna and forest shifting cultivation, located on the table lands (plateau) and in the valleys. In both cases, cassava was the main crop, but in other respects (crop rotations and associations, labour inputs, cropping calendar) the systems were different. Depending on the relative importance of savanna and forest fields, and on infrastructure and market access, several types of farm system would be found. There was a close relation between agro-ecological environment and market integration, the table lands being most isolated and most infertile in contrast to the more favourably situated valleys with relatively better soils. In many cases, however, farmers had access to both valley and plateau soils. Under increasing pressure to produce a surplus of cassava, farming had expanded onto more marginal soils, situated at great distances from the homestead. These plateau fields were farmed rather extensively and formed a reserve that could be drawn upon whenever valley fields produced insufficient or when sudden food shortages or cash emergencies were experienced. Thus, cassava yields on the table lands were a function of crop yields in the valley and labour availability.

Consequently, efforts to improve cassava productivity must be adapted to the constraints of the two types of cropping system and to farmers' objectives. If cassava yields on forest fields could be increased, the need to grow cassava on the poor plateau soils would decline and these soils could be planted with perennial crops (or at least with crops that are less likely to promote erosion) in order to ensure sustainability. 
While shifting cultivation based on cassava constituted by far the most important element of the farm systems in the area, small livestock were also kept and household gardens (near the homestead or on hydromorphic soils in the dry seasons) could also be found, albeit on a very limited scale. There appeared to be little scope for increasing farm system outputs through the small livestock and garden systems, at least in the near future.

Irrigated systems: wet-rice systems and other arable irrigation systems. Irrigation farming results from a gradual process of land-use intensification, during which agriculture expands onto hydromorphic soils (the shift from fallow to irrigation systems) and/or additional water sources are made available (the shift from permanent upland cropping) (Ruthenberg, 1980). The irrigated cropping systems can be extremely diverse, depending on cultivation techniques in the irrigated crop as well as on the cropping sequences on the irrigated field throughout the year. In wet-rice systems, it is common to distinguish multiple cropping arrangements as all-rice (single, double or triple cropping) or riceupland crops (Gomez and Gomez, 1983).

Furthermore, irrigated cropping systems, in particular wet rice, are nearly always found in combination with other cropping and livestock systems, as illustrated in Table 3 which indicates that wet-rice systems rank high in potential combinations with other systems. The resulting farm systems are therefore of great complexity, showing both farm level variations (irrigation combined with various other cropping and livestock systems) and cropping system level variations (multiple cropping arrangements).

Sugar cane-wheat farming in the Sind, Pakistan. Ruthenberg (1980) lists sugar cane-wheat holdings as one example where water availability modifies the irrigation system. Farm systems in the dry areas of the Sind consist of an irrigated cropping system, a rainfed cropping system and stationary animal husbandry. The irrigated cropping system is composed of two elements: a rainy season sugar cane crop grown on one-third of the farm land (because of limitations in water supply), and a wheat crop grown during the dry winter season, on about two-thirds of the farm land. The livestock system supplies the essential inputs of draught power and manure. On the non-irrigated parts of the holdings, berseem clover is grown in the winter and fodder sorghum in the summer season - both of which are fed to cattle, together with sugar cane tops. Milk, ghee and surplus fodder are sold. Cropping and livestock activities are intimately linked through the joint use of family labour. The farm system is characterized by a seasonal surplus of labour and animal power (184 and 204 days, respectively), which could be the focus of agricultural research aimed at a fuller use of household resources. The main limiting factor, however, appears to be irrigation water.

Rice-soyabean systems in Pasuruan, Indonesia. Javanese farmers in the Pasuruan district cultivate both irrigated lands (sawah) and uplands. The two cropping systems are closely related, as shown by the work of Soegito and colleagues (Soegito and Siemonsma, 1985; Soegito et al., 1986). The wetrice cropping system exists in two forms: rice followed by two dry season 
soyabean crops, or double-cropped rice followed by a single soyabean crop. The first soyabean crop after rice has a very short turn-around period so that field preparation is cursory and the seed is broadcast. No fertilizers are applied. The second, late dry season soyabean crop is planted after pre-germination by dibbling. If soyabean follows soyabean, the tillage required depends on the extent of weed infestation of the field.

The rice-soyabean type of cropping system relies on the cultivation of soyabean on uplands in order to provide fresh seed at the time of the rice harvest. Thus the two cropping systems are linked in a unique way, since the upland system provides an input for the wet-rice system - apart from the more common interaction and competition with respect to labour or capital.

On uplands, soyabean is also cultivated during the rainy season (simultaneously with the first rice crop in the sawahs). The seed is broadcast after ploughing and only manure is applied.

The understanding of the various cropping systems and their implications for management has had important consequences for soyabean breeding and testing. Among other things, on-farm trials showed that higher inputs for soyabean on sawahs did not yield a clear economic return (possibly as a result of the residual effects of the fertilizer used on the rice), whereas the use of fertilizer and insecticides on the uplands provided a net benefit.

Farm systems in the Basse Casamance, Senegal. The Casamance region (annual rainfall $1000 \mathrm{~mm}$ ) provides an interesting example of the intricate interactions between various wet-rice systems and permanent upland cultivation in combination with livestock (Sall et al., 1983).

Three types of cropping systems are distinguished: permanent upland cultivation with mainly groundnuts, a system which increases in importance in areas at higher altitude and with lower rainfall; a phreatic wet-rice system (see Moorman and Van Breemen, 1978, for exact definition of terms) on soils with high groundwater table; and a fluxial wet-rice system (Moorman and Van Breemen, 1978) which is always transplanted and occurs on several soil types (mainly mangrove swamps and acid sulphatic plains).

According to ethnic group, the division of labour is by task (land preparation by men, all other work by women), and/or by crop (rice cultivated by women, groundnuts by men). The availability of animal traction also influences the farm system and increases the farm area under cultivation. Thus, five types of farm systems were defined in the region.

Researchers attempted to develop technology tailored to the various farm systems by intensifying wet-rice production in the inland valleys and diversifying the upland crops. Because of labour constraints imposed by the wet-rice cropping system, emphasis was placed on late-seeded crops (sweet potato, cowpea, short cycle sorghum, millet) in the upland system. On the upper river terraces maize, which is less labour intensive than rice, successfully replaced rice which suffered too much from lack of moisture.

Semi-arid rainfed farm systems in west Asia. Farm systems of west Asia and 
north Africa, although not located in the tropics, provide interesting examples of the intricate linkages between livestock and cereals, and are therefore included here.

Cooper et al. (1987) and Tully (1986) provide detailed descriptions of rainfed farm systems in west Asia, and of barley-sheep systems in particular. Often found on shallow soils (Xerosols) in areas of $350 \mathrm{~mm}$ rainfall or less, barley is grown for food but mainly for animal feed, for which stubble, straw and sometimes grain is used. The main rotation is a two year barley-fallow, with summer crops grown on residual moisture in the wetter areas. As a result of declining soil fertility (due to the lack of chemical or animal manure) and the increased demand for feed (resulting from the increased demand for livestock products in urban areas), farmers have expanded barley cultivation onto the more marginal soils. Continuous barley cropping is also becoming more common, with fallows disappearing. The intimate linkage between barley and sheep production has several implications for the development of improved management practices in barley. The ubiquitous shortage of feed and the poor water storage efficiency of the fallow suggests that ways must be found to replace the fallow by continuous barley or by the introduction of annual forage legumes. ICARDA has therefore focussed its research on comparing water use efficiences of fallow/ barley, barley/barley and forage legume/barley rotations. Furthermore, the effect of fertilizers ( $N$ and $P$ ) on water use efficiency and yield (total dry matter) are being investigated.

High-altitude farm systems in the Peruvian Andes. Agriculture in maize producing areas of the Peruvian Andes occurs in three distinct ecological zones (Tardieu, 1976). In the low altitude zone $(2400-2600 \mathrm{~m}$, annual rainfall $200-$ $300 \mathrm{~mm}$ ), only irrigated agriculture is possible, with maize and potato as the main staple crops, in rotation with wheat, barley and horticultural crops. In the intermediate zone $(2600-3000 \mathrm{~m}$, annual rainfall $300-500 \mathrm{~mm})$, maize is graduaily replaced by other cereals (wheat, barley) and potatoes, but double cropping is impossible at this altitude. Mixed intercropping with beans (Vicia faba and Lupinus mutabilis) is also found. In the high altitude zone (over $3000 \mathrm{~m}$, annual rainfall $500-800 \mathrm{~mm}$ ) frost presents a serious risk. A potatobarley rotation is common on rainfed fields. Below $3200 \mathrm{~m}$, maize is intercropped with beans or indigenous crops such as quinoa (Chenopodium quinoa) and roots and tubers (Oxalis tuberosa, Ullucus tuberosus, Tropaeolum tuberosum). On high altitude fields (above about $3500 \mathrm{~m}$ ) only these indigenous crops occur, often in mixed intercropping. Alfalfa is grown over $3000 \mathrm{~m}$ if irrigation is available. Within the general limitations of climate and altitude, cropping systems differ according to the availability of irrigation water (usually from melting snow at the foot of the highest ranges) and slope. On steep slopes animal traction is replaced by hand cultivation with hoes.

The livestock system constitutes an essential element in the farm system, mainly because it supplies draught power, but also because it allows the farmer to make optimal use of his environment. Where altitude prohibits arable 
cropping, land is used for pasture. On the highest slopes llamas are kept, while the raising of small domestic animals (poultry, rabbits, sheep) constitutes an important activity for every household.

Because farmers' fields are usually located in more than one agro-ecological zone, farm systems in the area are characterized by a great diversity of cropping and livestock systems.

\section{CHANGES IN FARM SYSTEMS}

Describing the current characteristics of farm systems is clearly insufficient when it comes to defining the objectives of agricultural research for such systems. Research planning requires an understanding of the trends in the evolution of farm systems. While it is widely acknowledged that regional, landscape, farm, cropping, livestock, crop and animal systems change over time, and at different rates, there has been little attempt to document these changes.

It has been suggested that as a first response to increasing population pressure, shifting cultivation systems will expand their areas as long as land is not a limiting factor. However, land shortages soon lead to more labour-intensive methods in order to restore soil fertility (Boserup, 1965; Grigg, 1974). In this view, rural and urban population growth and, consequently, increased commercialization, determine the stages of evolution of farm systems. Ruthenberg (1980) has elaborated this hypothesis by indicating the evolutionary pathways of land-use in different agro-ecological zones.

In all cases, shifting cultivation systems move gradually towards permanent agriculture, either in the form of irrigation, permanent upland cropping, perennial cropping or intensive grazing systems (the latter two do not occur in semiarid climates). Richards (1985), however, has challenged this sequence, by suggesting that shifting cultivation in west Africa does not necessarily represent an early stage of agricultural development, but may have been a response to colonial demands for agricultural produce. Furthermore, there is ample evidence that changes in farm systems are not always caused by population pressure alone, but may result from chance factors, for example the introduction of new crop species by returning migrants, or the innovations developed by farmers themselves (such as the planting of rice in tidal swamps). Although the notion of evolution is fraught with difficulties, there is a need to move away from the 'stamp collection' approach to the study of changes in farm systems to an understanding of the transitions from one type to another.

In system terms, changes in farm systems occur through changes in higher or lower level systems. Important regional system changes are population growth and infrastructural or institutional developments such as the opening up of new markets. At the village/landscape unit level, changes in land and water availability will affect farming. The 20-30 year development cycle in a farm household will influence its labour and cash resources and consumption needs.

Cropping systems are transformed through various methods of intensifica- 
tion, in particular multiple cropping (to make a fuller use of the agricultural year), permanent land-use and the introduction of new, high-yielding varieties and crops with a higher harvest-index and input requirements than those of the traditional ones. Livestock systems may change into more specialized enterprises for meat and milk production, and animal traction and manure may be replaced by mechanization and fertilizers, thus reducing the complementary interaction between cropping and livestock that at present characterizes most of the tropical farm systems described.

Changes in farm systems therefore result from the interaction of a multitude of socio-economic variables with ecological factors at all levels in the hierarchy of systems. Their impact on concrete farm systems will differ widely and cannot be predicted fully with the current state of knowledge in simulation modelling and agricultural development theory.

In classifying farm systems, the key question remains what changes are relevant in what time perspective. For example, the replacement of an existing variety by one resistant to a disease or pest may not immediately alter the farm system with respect to labour and other input requirements. In the longer term, however, the increased yield and the corresponding increase in nutrient extraction from the soil may undermine the ecological stability of the system. Similarly, a change at the crop system level, such as the replacement of sorghum by maize, may not involve any profound changes at the farm system level because the function of the crop sub-system (and its input-output flow) remains unaltered. The introduction of maize, however, provides opportunities for the intensification of land-use that may become a focus of changes for the system as a whole. Or, to quote another example at the crop system level, the replacement of yam by cassava may not appear as a dramatic change in a shifting cultivation situation, but it could be a symptom of changes at other levels such as the deterioration of soil fertility or the decline of the agricultural labour force.

While the broad trends described by Boserup (1965) and Ruthenberg (1980) signal long-term changes from one system type to another, agricultural research is mostly concerned with improvements within a given type of farm system. Important areas of research in the CGIAR centres nearly always concern improvements to the existing system through the development of new varieties or improved cultural practices such as multiple cropping. One noticeable exception is IITA's work on alley cropping which aims, at least implicitly, to promote a change from shifting cultivation systems to permanent upland cultivation systems (e.g. IITA, 1984). As has been argued before (Simmonds, 1986) the time has come to focus research more clearly on the development of new farm systems, in other words on technology that enables farmers to make the transition from one farm system type to another. For this purpose, there are two prerequisites: an adequate classification of farm systems, and a study of the historical dynamics of these systems. 


\section{RE FERENCES}

Allan, W., Gluckman, M. \& Peters, D. U. (1945). Land Holding and Land Usage among the Plateau Tonga of Mazabuka District: a Reconnaissance Survey. Westport.

Beek, K. J. (1978). Land Evaluation for Agricultural Development. Wageningen: ILRI.

Boserup, E. (1965). The Conditions of Agricultural Growth. London: George Allen \& Unwin.

CGIAR/TAC (1985). TAC Review of CGIAR Priorities and Future Strategies. Rome: TAC Secretariat.

Collinson, M. P. (1984). Diagnosing the problems of small farmer needs. In Proceedings IVth Agricultural Sector Symposium, 124-146. Washington: World Bank.

Cooper, P. J. M., Gregory, P. J., Tulley, D. \& Harris, H. C. (1987). Improving water use efficiency of annual crops in the rainfed farming systems of West Asia and Northern Africa. Experimental Agriculture 23:113-158.

Duckharn, A. N. \& Masefield, G. B. (1970). Farming Systems of the World. London: Chatto \& Windus.

Fresco, L. O. (1986). Cassava in Shifting Cultivation A Systems Approach to Agricultural Technology Development in Africa. Amsterdam: Royal Tropical Institute.

Gomez, A. A. \& Gomez, K. A. (1983). Multiple Cropping in the Humid Tropics of Asia. Ottawa. IDRC.

Grigg, D. B. (1974). Agricultural Systems of the World. An Evolutionary Apptoach. Cambridge: Cambridge University Press.

Hart, R. D. (1982). One farm system in Honduras: a case study in farm systems research. In Readings in Farming Systems Research, 59-73 (Eds W. W. Shaner, M. Phillip and M. Schmehl). Boulder, Colorado: West view Press.

Hart, R. D. \& Pinchinat, A. M. (1982). Integrative agricultural systems research. In Caribbean Seminar on Farming Systems Research Methodology. Basse Terre, Guadeloupe: IICA/INRA.

Huisman, A. (1985). Choice and uncertainty in a semi-subsistence economy. A study of decision making in a Philippine village. PhD thesis Wageningen Agricultural University.

ICRISAT (1987). Looking Ahead: a 10-y ear Plan. Patancheru, India: ICRISAT.

IITA (1984). Annual Report 1983. Ibadan: IITA.

IRRI (1985). Women in rice farming. Conference Proceedings, IRRI, 26-30 September 1983. Hants, England: Gower.

Jackson, I. J. (1977). Climate, Water and Agriculture in the Tropics. London: Longman.

Lagemann, J. (1977). Traditional African Farming Systems in Eastern Nigeria Afrika-Studien 98. München: Weltforum Verlag.

McDowell, R. E. \& Hildebrand, P. E. (1983). Integrating Crop and Animal Production: Making the Most of Resources Available to Small Farms in the Developing Countries. The Rockefeller Foundation.

McIntire, J. \& Gryseels, G. (1987). Crop-livestock interactions in sub-Saharan Africa and their implications for farming bystems research. Experimental Agriculture 23:235-243.

Miracle, M. (1967). Shifting Cultivation in the Congo Basim Madison, USA: University of Wisconsin Press.

Mohr, E. C. J., Van Baren, F. A. \& Van Schuylenborch, J. (1972). Tropical Soils. The Hague: Mouton.

Moorman, F. R. \& Van Breemen, N. (1978). Rice: Soil, Water, Land. Los Baños: IRRI.

Nair, P. K. R. (1985). Classification of agro-forestry systems. Agroforestry Systems 3:97-128.

Nieuwolt, S. (1977). Tropical Climatology. An Introduction to the Climates of the Low Latitudes. London: John Wiley \& Sons.

Odum, H. T. (1983). Systems Ecology. New York: John Wiley \& Sons.

Richards, P. (1985). Indigenous Agricultural Revohtion: Ecology and Food Production in West Africa. London/Boulder, Colorado: Hutchinson/West view Press.

Ruthenberg, H. (1980). Farming Systems in the Tropics. Third Edition Oxford: Clarendon Press.

Sall, S., Kamuanga, M. \& Posner, J. (1983). La Recherche sur les Systèmes de Production en Basse-Casamance. Djibelor: ISRA.

Sanchez, P. A. (1976). Properties and Management of Soils in the Tropics. New York and London: John Wiley \& Sons.

Schaar, J. (1981). The Link between Man and Soil - on the Role of Livestock in Tropical Farming Systems. Rural Development Studies 10. Uppsala: Swedish University of Agricultural Sciences.

Simmonds, N. W. (1986). A short review of Farming Systems Research in the tropics. Experimental Agriculture 22:1-13.

Soegito, Siemonsma, J. S., Sutrisno \& Henny Kunt yastuti.(1986). Soybean on-farm yield trials in Pasuruan. Penelition Palawija 1:16-25.

Soegito \& Siemonsma, J. S. (1985). Soybean Improvement Paper 1 (On-farm Programme Wonorejo). Melang: MARIF.

Spedding, C. R. W. (1979). An Introduction to Agricultural Systems. London: Applied Science Publishers. 
Tardieu, F. (1976). Sistemas de Cultivo en la Zona Maicera del Callejón de Huaylas. Lima, Perú: Universidad Nacional Agraria 'La Molina'.

Tully, D. (1986). Rainfed farming systems of the Near East region. In Proceedings of Workshop on Soil, Water and Crop/Livestock Systems for Rainfed Agriculture in the Near East Region. Amman, Jordan.

Webster, C. C. \& Wilson, P. N. (1980). Agriculture in the Tropics. Second Edition. London: Longman.

Westphal, E. (1975). Agricultural Systems in Ethiopia. Wageningen: Pudoc.

Westphal, E., Embrechts, J., Mbouemboue, P., Mouzong Boyomo \& Westphal-Stevels, J. M. C. (1981). L'agriculture autochtone au Cameroun: les techniques culturales, les séquences de culture, les plantes alimentaires et leur consommation. In Miscellaneous Papers 20. Landbouwhogeschool, Wageningen: Agricultural University. 